\title{
PENGGUNAAN MULTIMEDIA ANIMASI UNTUK MENINGKATKAN KEMAMPUAN BERPIKIR KRITIS DALAM PEMBELAJARAN MATERI PENGUATAN LOGAM PADA MATA KULIAH MATERIAL TEKNIK
}

\author{
Zevi M. Fratandha ${ }^{1}$, Amay Suherman ${ }^{2}$, Mumu Komaro ${ }^{3}$ \\ Departemen Pendidikan Teknik Mesin \\ Universitas Pendidikan Indonesia \\ Jl. Dr. Setiabudhi No. 207 Bandung 40154 \\ zevimf@yahoo.com
}

\begin{abstract}
ABSTRAK
Penelitian ini bertujuan untuk mengetahui perbedaan peningkatan kemampuan berpikir kritis mahasiswa DPTM UPI pada pembelajaran materi Penguatan Logam dengan menerapkan pembelajaran menggunakan multimedia animasi dibandingkan dengan menggunakan diktat. Metode penelitian yang digunakan dalam penelitian ini adalah metode kuantitatif, dengan menggunaan pola desain Nonequivalent Control Group Design. Teknik Pengumpulan data dilakuan dengan menggunakan tes soal essay yang dilakukan sebelum dan sesudah mahasiswa diberikan treatment. Hasil penelitian dilihat dari nilai rata-rata $N$-Gain dari masingmasing kelompok menunjukan peningkatan kemampuan berpikir kritis pada kelompok yang menggunakan multimedia animasi dalam pembelajarannya yang berada pada kategori sedang lebih baik dibandingkan peningkatan kemampuan berpikir kritis pada kelompok yang menggunakan media diktat dalam pembelajarannya yang berada pada kategori rendah.
\end{abstract}

Kata kunci: multimedia animasi, berpikir kritis, penguatan logam

\section{PENDAHULUAN}

Material teknik dalam kurikulum Departemen Pendidikan Teknik Mesin (DPTM), merupakan mata kuliah dasar yang termasuk dalam kelompok mata kuliah keahlian bidang studi. Mata kuliah Material Teknik ini dipelajari oleh mahasiswa pada semester satu dengan jumlah kredit 2 SKS. Mata kuliah Material Teknik sangat diperlukan untuk menunjang pembelajaran pada mata kuliah keahlian program studi lanjutan, diantaranya; Teknik Pengelasan, Fabrikasi Logam, Teknik Pengecoran, Teknik Penyambungan, Teknik Pemesinan, Chasis Otomotif, Body Otomotif, Elemen Mesin I, dan Elemen Mesin II. Mata kuliah ini sangat penting karena diberikan kepada tiga konsentrasi yang ada di Departemen Pendidikan Teknik Mesin yaitu; konsentrasi Produksi dan Perancangan, konsentrasi Otomotif, serta konsentrasi Refrigerasi dan Tata Udara.

Mata kuliah material teknik ini dinilai penting karena mata kuliah ini merupakan mata kuliah prasyarat untuk menempuh mata kuliah lanjutan yang berhubungan dengan sifat mekanik dan sifat logam. Pada saat penyampaian materinya harus benar-benar jelas dan tepat agar mudah dimengerti dan dipahami oleh mahasiswa. Material teknik ini

\footnotetext{
${ }^{1}$ Mahasiswa Departemen Pendidikan Teknik Mesin FPTK UPI

${ }^{2}$ Dosen Departemen Pendidikan Teknik Mesin FPTK UPI

${ }^{3}$ Dosen Departemen Pendidikan Teknik Mesin FPTK UPI
} 
merupakan mata kuliah yang memiliki pokok-pokok bahasan dalam proses pembelajarannya. Salah satu pokok bahasan yang disampaikan pada mata kuliah material teknik ini yaitu pokok bahasan penguatan logam. Pokok bahasan penguatan logam ini memiliki beberapa pokok materi yang harus disampaikan kepada peserta didik yaitu dislokasi, penghalusan butir, perlakuan panas dan pemaduan. Penguatan logam merupakan salah satu pokok bahasan pada mata kuliah material teknik yang dalam proses pembelajarannya mahasiswa diharuskan untuk menguasai pokok-pokok bahasan sebelumnya (Dahar, 2011). Pokok bahasan struktur kristal, bidang geser dan cacat kristal. Mata kuliah ini juga dinilai memiliki karakteristik dan tingkat kesulitan pada masingmasing pokok bahasannya.

Tingkat kesulitan yang dihadapi pada proses pembelajaran yang dialami mahasiswa dapat diketahui dengan data yang dimiliki oleh dosen material teknik. Data tersebut dilakukan terhadap 32 mahasiswa yang telah menempuh mata kuliah material teknik. Hasil yang dihadapi mahasiswa dalam menempuh mata kuliah material teknik. Tingkat kesulitan yang dihadapi oleh mahasiswa pada pembelajaran struktur kristal atom. Sebanyak 60\% mahasiswa mengalami kesulitan pada pokok pembahasan bidang geser atom, 20\% mahasiswa mengalami kesulitan pada pokok pembahasan penguatan logam, dan $20 \%$ mahasiswa yang mengalami kesulitan pada pokok pembahasan struktur kristal atom. Kesulitan tersebut khususnya pada pokok bahasan penguatan logam dinilai cukup tinggi dan dapat menjadi kendala yang besar pada proses pembelajaran (Djamarah dan Zain, 2006). Pokok bahasan ini menuntut mahasiswa untuk memiliki hasil/output yakni mahasiswa mampu berpikir kritis.

Berpikir kritis adalah kemampuan berpikir secara beralasan dan reflektif dengan menekankan pada pembuatan keputusan tentang apa yang harus dipercayai atau dilakukan (Hassoubah, 2004). Mengingat betapa pentingnya kemampuan tersebut maka dalam proses penguasaan materi mengenai pokok bahasan ini diperlukan suatu upaya yang mampu membentuk mahasiswa berpikir kritis dalam menghadapi kesulitan yang ada. Kemampuan berpikir kritis ini dapat membuat mahasiswa memiliki kemampuan untuk mengidentifikasi, menganalisa serta mengetahui inti permasalahan yang dihadapi sehingga dapat menemukan serta menentukan solusi/jalan keluar yang tepat untuk memecahkan permasalahan yang ada. Sebagai contoh perlunya kemampuan berpikir kritis dapat kita lihat pada proses pembelajaran fisika. Dalam proses pembelajaran fisika mahasiswa diberikan suatu kasus yang harus dipecahkan, sebelum memecahkan kasus dalam pembelajaran tersebut mahasiswa harus mampu mengidentifikasi, menganalisis serta 
mengetahui inti permasahan sehingga solusi untuk memecahkan kasus tersebut dapat diperoleh (Wena, 2009).

Kesulitan khususnya penguatan logam tersebut muncul diakibatkan oleh beberapa hal, yakni kurangnya referensi yang dimiliki, referensi yang ada sulit untuk dimengerti karena menggunakan bahasa asing. Kurangnnya media pembelajaran yang dapat mengatasi kendala yang ada serta karakteristik pokok bahasan penguatan logam yang abstrak yakni proses atom pada bahasan ini sulit dilihat dengan mata langsung. Dinamis yang berarti bahwa pergerakan atom dalam proses penguatan logam tidak selalu sama arah serta pergerakannya dan kompleks (Slameto, 2010). Pokok bahasan ini memiliki dampak pada hasil dari proses penguatannya sehingga mengakibatkan upaya dalam merangsang mahasiswa untuk berpikir kritis masih sulit untuk dilakukan. Mengingat sangat pentingnya mata kuliah material teknik ini, maka mahasiswa diharapkan mampu menguasai materimateri pokok pada pembelajarannya. Khususnya pada tingkat kognitif analisis (berpikir kritis) yang ditandai dengan mampunya mahasiswa untuk menganalisis, memberikan bukti, mengidentifikasi alasan, dan menyimpulkan dari permasalahan-permasalahan yang ada (Kowiyah, 2012). Hasil penelitian yang sudah dilakukan oleh dosen material teknik di atas menunjukkan bahwa diperlukan adanya upaya yang dapat mengatasi kesulitan-kesulitan yang ada, ini dikarenakan kesulitan kesulitan yang dihadapi dapat berpengaruh terhadap hasil pembelajaran.

Penyebab diakibatkan model teoritis berupa simbol-simbol verbal maupun media/alat bantu pembelajaran yang tersedia (Purnawan, 2006). Tidak hanya cukup representatif untuk dapat menjelaskan konsep suatu sistem secara realistis, sehingga kemungkinan tidak terjangkau (inaccessible) oleh peserta didik yang efeknya kurang menimbulkan pengalaman belajar. Usaha lain yang berhubungan dengan masalah buku teks asli dan kendala bahasa. Diperlukan media pembelajarkan berbahasa Indonesia untuk materi yang diperlukan yang diambil dari buku teks aslinya.

Berdasar pada kenyataan yang ada pada proses pembelajaran materi penguatan logam, maka diperlukan suatu upaya perbaikan agar proses pembelajaran tidak menjadi sulit. Mudah dipahami serta dijelaskan dalam bahasa Indonesia sehingga bahasan tersebut dapat dipelajari secara berulang. Salah satu cara melakukan perbaikan tersebut yaitu dengan menggunakan multimedia animasi. Media ini dinilai mampu melakukan perbaikan karena media jenis ini cukup terjangkau (accessible) sehingga memungkinkan suatu bahan dapat dipelajari secara berulang. Penggunaan media jenis ini tidak akan terlepas dari suatu alat yang dapat menampilkannya (Rusman, dkk. 2012). Contoh alat yang dapat 
menampilkan media jenis ini yaitu komputer/laptop. Hasil penelitian awal menunjukkan sebanyak $81 \%$ mahasiswa memiliki komputer/laptop pada tahun pertama dan $97 \%$ mahasiswa memiliki komputer/laptop pada tahun kedua. Dimana dalam hal ini kepemilikan komputer/laptop tersebut menjadi peluang untuk mengembangkan proses pembelajaran menggunakan komputer yang bisa mengatasi permasalahan dalam proses pembelajaran material teknik khususnya konsep atom yang bersifat abstrak, dan kompleks akan lebih mudah untuk dipahami dan dimengerti dengan menggunakan multimedia animasi (Sanjaya, 2010).

Multimedia animasi yang digunakan adalah multimedia adobe flash actionscript 2 karena dinilai paling tepat oleh penulis sebagai solusi untuk konsep atom yang bersifat abstrak dan kompleks. Multimedia ini memiliki keunggulan dalam penggunaannya dibandingkan dengan multimedia animasi yang lainnya adalah mudah dipelajari bagi seorang pemula yang masih awam dengan dunia desain, pengguna dapat dengan mudah dan bebas dalam berkreasi membuat animasi dengan gerakan bebas sesuai dengan alur adegan yang dikehendaki, dapat menghasilkan file yang ukurannya kecil. Karena flash menggunakan animasi yang berbasis vektof, menghasilkan file bertipe FLA yang bersifat fleksibel, karena dapat dikonversikan menjadi tipe .swf, .html, .gif, .png, .exe, .mov.

Tujuan penelitian ini adalah sebagai berikut: mengetahui peningkatan kemampuan berpikir kritis mahasiswa dalam pembelajaran materi penguatan logam pada mata kuliah material teknik dengan menggunakan diktat, mengetahui peningkatan kemampuan berpikir kritis mahasiswa, dan mengetahui perbedaan peningkatan kemampuan berpikir kritis mahasiswa.

\section{METODE PENELITIAN}

Desain yang akan digunakan dalam penelitian ini adalah Quasi Experimental Design dalam bentuk nonequivalent control group design. Sampel yang dipilih tidak secara acak, sehingga desain penelitian ini cocok dengan penelitian ini. Kelompok kontrol diperlukan untuk melihat sejauh mana peningkatan berpikir kritis dengan pembelajaran menggunakan multimedia animasi, yang selanjutnya dibandingkan dengan kelompok pembelajaran menggunakan multimedia animasi.

\section{HASIL PENELITIAN}


Penelitian ini dilakukan terhadap mahasiswa angkatan 2014 yang berada di Depertemen Pendidikan Teknik Mesin UPI Bandung. Sampel yang digunakan masingmasing berjumlah 15 orang pada kelas kontrol dan kelas eksperimen, data yang telah diperoleh dari penelitian ini adalah data pre-tes dan post-tes dari kedua kelas baik kelas kontrol maupun kelas eksperimen. Data-data tersebut digunakan untuk mendeskrifsikan secara kuantitatif sehingga dapat diperoleh kesimpulan dari hasil penelitian tersebut.

Data judgment materi dan soal yang dibuat pada penelitian ini adalah keterangan yang benar dan nyata untuk menilai isi materi yang akan digunakan dalam penelitian yang dinilai oleh Ahli Materi UPI, judgment ini dinilai oleh pakar. Data judgment ini digunakan sebagai landasan bahwa isi materi di dalam multimedia animasi dan materi pembelajaran yang telah dibuat layak untuk digunakan dalam penelitian ini. Jika materi yang telah dibuat sudah dinyatakan layak, maka materi akan dikatakan valid oleh pakar. Lembar format judgment oleh pakar yang dibuat berbentuk skala rating scale yang terdiri dari 10 butir pernyataan.

Data judgment multimedia yang dibuat pada penelitian ini adalah keterangan benar dan nyata untuk menilai multimedia secara fisik dan isi dari materi multimedia tersebut, judgment ini dinilai oleh pakar dengan mengisi lembar judgment. Penilaian tersebut dimaksudkan untuk menilai fisik multimedia dan dinilai secara umum apakah media yang sudah dibuat layak untuk digunakan atau tidak. Multimedia animasi yang sudah dibuat layak untuk digunakan setelah dinilai oleh ahli media. Lembar format judgment oleh pakar media yang dibuat berbentuk skala pengukuran rating scale yang terdiri dari 17 butir pernyataan.

Data uji coba instrument soal test dalam penelitian ini adalah keterangan yang benar dan nyata dari pakar materi. Kesesuaian soal dengan pencapaian indikator, kesesuaian dengan aspek hasil belajar, serta tingkat kesulitannya. Penilaian soal yang dilakukan oleh pakar materi untuk acuan agar menentukan soal test yang dilakukan dalam penelitian nanti. Jika soal test sudah sesuai dengan penilaian ahli materi maka soal layak untuk digunakan dalam penelitian.

Data pre-test dan post-test dalam penelitian ini adalah keterangan yang benar dan nyata yang diperoleh dari uji lapangan pre-test dan post-test terhadap dua kelompok yaitu kelompok kontrol dan kelompok eksperimen. Data pre-test merupakan data awal yang dilakukan penelitian kepada mahasiswa angkatan 2014 dari kedua kelomok sampel sebelum diberikan treatment yang berbeda antara kelompok kontrol diberikan treatment berupa diktat sedangkan kelompok eksperimen diberikan treatment berupa multimedia 
animasi, sehingga data pre-test kedua kelompok sampel akan digunakan untuk menguji homogenitas sampel penelitian. Uji homogenitas dari data pre-test kedua kelompok sampel yaitu kelompok kontrol dan kelompok eksperimen, sedangkan untuk uji normalitas diambil dari data pre-test dan post-test kedua kelompok sampel yaitu kelompok kontrol dan kelompok eksperimen yang akan digunakan sebagai landasan penggunaan rumus uji t pada uji hipotesis.

Data pre-test dan post-test dari kedua kelompok yaitu kelompok kontrol maupun kelompok eksperimen harus berdistribusi normal. Selain sebagai landasan untuk uji hipotesis, data pre-test dan post-test dari kedua kelompok sampel yaitu kelompok kontrol dan kelompok eksperimen juga digunakan untuk mendapatkan data peningkatan hasil belajar (Gain) yang selanjutnya diolah menjadi data normalitas peningkatan hasil belajar (N-Gain).

Tabel 1. Hasil pre-test,post-test dan n-gain

\begin{tabular}{|c|c|c|c|c|}
\hline \multicolumn{2}{|c|}{ Kelompok Kelas } & Pre-test & Post-test & $N$-Gain \\
\hline \multirow{3}{*}{ Eksperimen } & Tertinggi & 37,5 & 87,8 & 0,81 \\
\hline & Terendah & 22,5 & 62,5 & 0,29 \\
\hline & Rata-Rata & 29,7 & 72,17 & 0,53 \\
\hline \multirow{3}{*}{ Kontrol } & Tertinggi & 32,5 & 62,5 & 0,59 \\
\hline & Terendah & 17,5 & 25 & 0,13 \\
\hline & Rata-Rata & 25,2 & 39,67 & 0,283 \\
\hline
\end{tabular}

Nilai rata-rata pre-test kelas kontrol (Tabel 1) adalah 25,2 sedangkan kelas eksperimen 29,7, data ini menunjukan adanya perbedaan antara kedua kelompok yaitu kelompok kontrol dan kelompok eksperimen yang tidak begitu signifikan. Hal ini menunjukan bahwa kemampuan rata-rata mahasiswa kelompok kontrol dan kelompok eksperimen hampir sama. Data tersebut diperkuat juga dengan pengujian homogenitas terhadap kedua kelompok antara kelompok kontrol dan kelompok eksperimen dengan menggunakan uji F, didapatkan bahwa kedua sampel kelompok homogen dengan taraf signifikansi sebesar $42 \%$, nilai ini lebih besar dari nilai yang sudah ditentukan yaitu sebesar 5\%. Ini berarti bahwa kedua sampel kelompok tersebut homogen sehingga kedua kelas dapat digunakan untuk penelitian dan diberikan treatment. Data post-test menunjukan bahwa kelompok eksperimen lebih tinggi dibandingkan dengan kelompok post-test kontrol, hal tersebut terlihat pada perbedaan rata-rata nilai post-test kelompok eksperimen yang lebih besar dari kelompok kontrol. Kelompok kontrol dengan proses pembelajaran menggunakan diktat hanya mencapai nilai rata-rata sebesar 39,67, sedangkan kelas eksperimen yang menggunakan MMA mencapai nilai rata-rata sebesar 72,17. 
Uji homogenitas yang telah dilakukan terhadap data hasil pre-test kelompok kontrol dan kelompok eksperimen telah menghasilkan nilai $F_{\text {hitung }}$ adalah 1,111 , dan nilai $F_{\text {tabel }}$ adalah 2,483. Berdasarkan perbandingan nilai $\mathrm{F}$ pada hasil uji homogenitas adalah $\mathrm{F}_{\text {hitung }}<$ $\mathrm{F}_{\text {tabel}}$, maka data dapat dikatakan kedua varian relatif sama. Nilai $p$-value yang didapat dari hasil perhitungan adalah 0,423 , dengan nilai $\alpha 0,05$. Berdasarkan nilai p-value yang didapat yaitu $p$-value $>\alpha$, maka dapat dikatakan bahwa pengujian homogenitas yang telah dilakukan berada pada daerah penerimaan homogen yang bertaraf signifikansi sebesar $42,3 \%$.

Hasil varian kedua kelompok sampel homogen, maka untuk pengujian pada penelitian ini bisa dapat dilanjutkan dengan menggunakan analisis data Statistik Parametrik metode uji $\mathrm{t}$ dan dengan jumlah anggota sampel $\mathrm{n}_{1}=\mathrm{n}_{2}$ dan varian homogen $\left(\sigma_{1}{ }^{2}=\sigma_{2}{ }^{2}\right)$ maka untuk penelitian ini dapat menggunakan rumus t-test 3.16 maupun 3.17. Untuk melihat harga t-tabel menggunakan $\mathrm{dk}=\mathrm{n}_{1}+\mathrm{n}_{2}-2$.

Pengolahan data dapat dibagi menjadi dua, yaitu uji $N$-Gain dan uji t. Hasil perhitungan data pre-test dan post-test kelompok kontrol serta kelompok eksperimen didapatkan nilai rata-rata Gain 5,80 untuk kelompok sampel kontrol dan untuk kelompok sampel eksperimen didapatkan nilai rata-rata Gain 17,00. Setelah perhitungan Gain didapatkan maka nilai rata-rata Gain dari masing-masing kelompok sampel yaitu kelompok kontrol dan kelompok eksperimen selanjutnya data dihitung lagi menjadi nilai $N$-Gain yang telah menghasilkan nilai rata-rata $N$-Gain untuk kelompok kontrol adalah 0,196 dan nilai rata-rata $N$-Gain untuk kelompok eksperimen adalah 0,605.

Kedua nilai rata-rata $N$-Gain kelompok sampel dibandingkan, nilai rata-rata $N$-Gain kelompok eksperimen lebih besar dan masuk ke dalam kriteria sedang sedangkan nilai rata-rata $N$-Gain kelompok kontrol lebih kecil dan masuk ke dalam kriteria rendah. Berdasarkan hasil perhitungan $N$-Gain dapat dikatakan bahwa kelompok eksperimen lebih baik peningkatannya dalam berpikir kritis dibandingkan dengan kelompok kontrol.

Pengujian uji t yang dilakukan terhadap pada data $N$-Gain dengan kelompok sampel yaitu kelompok kontrol dan kelompok eksperimen dengan taraf signifikansi $\alpha=$ $0,05, \mathrm{dk}=28$, serta pengujian pihak kanan yang telah menghasilkan nilai $\mathrm{t}_{\text {hitung }}$ sebesar 11,063, dan nilai $\mathrm{t}_{(0,95 ; 28)}$ sebesar 2,048. Berdasarkan perbandingan karena nilai $\mathrm{t}$ adalah $\mathrm{t}_{\text {hitung }}>\mathrm{t}_{\text {tabel}}$, maka $\mathrm{t}_{\text {hitung }}$ berada pada derah penolakan $\mathrm{H}_{\mathrm{o}}$ yang terlihat pada Gambar 4.5. 
$\mathrm{H}_{\mathrm{o}}$ ditolak dan $\mathrm{H}_{\mathrm{a}}$ diterima, jika dilihat dari nilai $N$-Gain kelompok sampel eksperimen lebih baik dibandingkan dengan $N$-Gain yang kelompok sampel kontrol. Keputusan bahwa $\mathrm{H}_{\mathrm{o}}$ ditolak $\mathrm{d}_{\mathrm{d}} \mathrm{H}_{\mathrm{a}}$ diterima diperkuat dengan perhitungan $p$-value. Dilihat nilai $p$-value $(0,00)<\alpha(0,05)$ karena resiko sebesar $0,00 \%$ lebih kecil dibandingkan dengan taraf signifikansi yang telah ditetapkan sebesar 5\% maka peneliti berani menolak $\mathrm{H}_{\mathrm{o}}$ dan menerima $\mathrm{H}_{\mathrm{a}}$. Berdasarkan dari pengujian uji t, maka dapat dikatakan bahwa peningkatan kemampuan berpikir kritis kelompok eksperimen lebih baik daripada peningkatan berpikir kritis kelompok kontrol, maka dari itu peningkatan kemampuan berpikir kritis kelompok eksperimen dengan menggunakan MMA lebih baik dibandingkan dengan peningkatan kemampuan berpikir kritis kelompok kontrol yang hanya menggunakan diktat pada proses pembelajarannya.

\section{PEMBAHASAN}

Hasil pengolahan data pre-test dan post-test yang dilakukan terhadap penelitian ini telah menunjukan bahwa adanya peningkatan kemampuan berpikir kritis pada mahasiswa yang dalam pembelajarannya diberikan multimedia animasi, dilihat dari hasil perhitungan post-test dan perhitungan nilai rata-rata $N$-Gain kelompok eksperimen dengan jumlah nilainya yang lebih besar dibandingkan dengan kelompok kontrol. Diketahui bahwa dalam pembelajarannya kelompok eksperimen menggunakan multimedia animasi sedangkan kelompok kontrol dalam pembelajarannya yang hanya menggunakan diktat.

Perbedaan peningkatan hasil belajar pada kedua kelompok sampel yaitu kelompok kontrol dan kelompok eksperimen juga sejalan dengan hasil perhitungan yang menggunakan pengujian uji t, yang telah menghasilkan keputusan $\mathrm{H}_{\mathrm{o}}$ ditolak dan $\mathrm{H}_{\mathrm{a}}$ diterima. Artinya nilai $N$-Gain kelompok sampel eksperimen lebih baik dibandingkan dengan nilai $\mathrm{N}$-Gain kelompok sampel kontrol. Keputusan pengambilan bahwa $\mathrm{H}_{\mathrm{o}}$ ditolak dan $\mathrm{H}_{\mathrm{a}}$ diterima, didukung dengan hasil perhitugan yang telah dilakukan terhadap nilai $p$ value pada pengujian uji t. Berdasarkan nilai $p$-value yang lebih kecil dibandingkan dengan nilai $\alpha$, artinya resiko kesalahan yang dihadapi oleh peneliti dalam mengambil keputusan menolak $\mathrm{H}_{\mathrm{o}}$ padahal $\mathrm{H}_{\mathrm{o}}$ benar, sehingga peneliti berani menolak $\mathrm{H}_{\mathrm{o}}$ dan menerima $\mathrm{H}_{\mathrm{a}}$. Kelompok eksperimen diberika multimedia animasi dalam pembelajarannya sedangkan kelompok kontrol dalam pembelajarannya diberikan diktat, dan nilai $N$-Gain merupakan peningkatan kemapuan berpikir kritis. Peningkatan kemampuan berpikir kritis mahasiswa pada materi penguatan logam yang menggunakan multimedia animasi dalam pembelajarannya dapat dikatakan lebih baik dari pada peningkatan kemampuan berpikir 
kritis mahasiswa yang menggunakan diktat dalam proses pembelajarannya, dengan demikian bahwa rumusan hipotesis dalam penelitian ini dapat diterima.

Terdapat peningkatan kemampuan berpikir kritis mahasiswa yang menggunakan multimedia animasi dalam pembelajarannya dibandingkan dengan peningkatan kemampuan berpikir kritis yang menggunakan diktat. Pembelajaran dengan menggunakan multimedia animasi dapat meningkatkan kemampuan berpikir kritis mahasiswa yang lebih baik daripada pembelajaran yang hanya menggunakan diktat. Peningkatan kemampaun berpikir kritis mahasiswa yang menggunakan multimedia animasi dalam proses pembelajarannya berkaitan dengan ciri serta karakteristik dari multimedia animasi itu sendiri. Multimedia animasi termasuk kedalam media hasil penggabungan teknologi cetak dan komputer yang menggabungkan antara teks, gambar atau visual yang statis dan dinamis serta audio yang semua ini dikendalikan oleh komputer (Arsyad, 2013). Sehingga dalam prosesnya melibatkan banyak interaktivitas. Multimedia animasi dinilai dapat merangsang untuk melakukan latihan, simulasi dan lain sebagainya. Animasi dapat menambahkan kesan realisme, dapat merangsang mengadakan latihan, kegiatan laboratorium, simulasi dan sebagainya (Sudjana dan Rivai, 1989). Hal tersebut dipengaruhi dari hasil manipulasi teoritis (gambar) menjadi realistis sehingga menarik perhatian pengguna animasi untuk belajar.

Mahasiswa yang menggunakan animasi, untuk mahasiswa yang hanya menggunakan diktat dalam proses pembelajarannya memiliki hasil kemampuan berpikir kritis yang lebih rendah. Hal ini sangat berkaitan dengan karakter yang dimiliki oleh diktat sebagai media pada proses pembelajaran. Diktat merupakan media yang termasuk kedalam teknologi cetak yang memiliki salah satu ciri yaitu teks dan visual yang ditampilkan secara statis (diam). Ciri diktat tersebut yang statis, daya tarik yang dihasilkan kurang dapat membuat mahasiswa memberikan perhatiannya pada proses pembelajaran berlangsung. Dikaitkan dengan mata kuliah material teknik banyak menjelaskan mengenai hal yang tak kasat mata atai mikroskopis. Jenis media diktat ini kurang dapat memfasilitasi keadaan tersebut yang menyebabkan mahasiswa kesulitan untuk menggambarkan materi yang disampaikan.

Penggunaan media diktat dalam pembelarajan maupun media animasi pada proses pembelajarannya dapat meningkatkan kemampuan berpikir kritis mahasiswa. Hal ini didukung oleh hasil data penelitian dengan melihat peningkatan nilai hasil pembelajaran mahasiswa setelah diberikan treatment dari kelompok sampel kontrol maupun kelompok sampel eksperimen. Media meningkatkan kemampuan keterbacaan baru. Perbedaan 
penggunaan media diktat dan multimedia animasi dalam proses pembelajarannya terdapat dari hasil yang didapatnya. Perbedaannya terdapat pada peningkatan nilai hasil belajar yang merupakan peningkatan kemampuan berpikir kritis pada penelitian ini.

Rendahnya peningkatan hasil belajar pada kelompok sampel kontrol tidak terlepas dari proses pembelajarannya yang hanya menggunakan diktat. Penyajian media melalui diktat kurang menjelaskan teori dari Penguatan Logam. Pada media animasi materi definisi Penguatan Logam salah satunya memberikan contoh dari pergerakan-pergerakan atom bidang kristal. Sedangkan media diktat hanya menyajikan visualisasi atom berupa gambar, animasi dari pergerakan-pergerakan atom tersebut akan lebih memperjelas dan mempermudah mahasiswa untuk memahami materi pembelajaran dengan baik. Pembelajaran pada materi penguatan logam yang didalamnya terdapat pergerakanpergerakan atom ini dapat dibantu dengan menggunakan media animasi. Sedangkan tanpa menggunakan media animasi proses pembelajaran Penguatan Logam tidak akan berjalan dengan optimal (Warsita, 2008). Animasi dapat membantu proses pelajaran apabila peserta diklat hanya akan dapat melakukan proses kognitif. Sedangkan tanpa animasi proses kognitif tidak dapat dilakukan.

Materi penguatan logam merupakan materi dengan konsep yang abstrak, dinamis, dan kompleks. Konsep yang abstrak, dinamis, dan kompleks ini sulit dijelaskan jika dengan menggunakan gambar atau kata-kata saja. Sehingga peningkatan penguasaan konsep dengan menggunakan multimedia animasi akan lebih baik daripada peningkatan penguasaan konsep dengan menggunakan media diktat (Arsyad, 2013). Uraian pembahasan diatas dapat memberikan gambaran bahwa penggunaan multimedia animasi penguatan logam dapat meningkatkan kemampuan berpikir kritis mahasiswa menjadi lebih baik dibandingkan dengan media yang digunakan oleh dosen sebelumnya yang hanya berupa media diktat.

\section{KESIMPULAN}

Penelitian dapat disimpulkan, sebagai berikut: peningkatan kemampuan berpikir kritis mahasiswa dalam pembelajaran materi penguatan logam dengan menggunakan diktat rata-rata nilai $\mathrm{N}$-Gain nya berada pada kategori rendah. Peningkatan kemampuan berpikir kritis mahasiswa dalam pembelajaran penguatan logam dengan menggunakan multimedia animasi rata-rata nilai $N$-Gain nya berada pada kategori sedang. Terdapatnya perbedaan peningkatan kemampuan berpikir kritis antara mahasiswa yang pembelajarannya menggunakan multimedia animasi lebih baik dibandingkan dengan yang hanya 
menggunakan diktat. Pembelajaran dengan menggunakan multimedia animasi dapat memberikan peningkatan kemampuan berpikir kritis mahasiswa yang lebih baik dibandingkan dengan pembelajaran yang menggunakan diktat.

\section{DAFTAR PUSTAKA}

Arsyad, A. (2013). Media Pembelajaran. Jakarta: PT. Raja Grafindo Persada.

Dahar, R.W. (2011). Teori-teori Belajar dan Pembelajaran. Jakarta: Erlangga.

Djamarah, S. B. dan Zain, A. (2006). Strategi BelajarMengajar. Jakarta: Rineka Cipta.

Fisher, A. (2009). Berpikir Kritis: Sebuah Pengantar. Jakarta: Erlangga.

Hamalik, O. (2004). Proses Belajar mengajar.Jakarta: Bumi Aksara.

Ibrahim. (2001). Pembelajaran Kooperatif. Surabaya: University Press.

Hassoubah, Z. I. (2004). Cara Berpikir Kritis dan Kreatif, Bandung: Nuansa Cendekia.

Kowiyah. (2012). Kemampuan Berpikir Kritis. Jurnal Pendidikan Dasar, 3 (5), hlm.175179.

Munir. (2010). Kurikulum Berbasis Teknologi Informasi dan Komunikasi. Cetakan kedua. Bandung: Alfabetha.

Purnawan. (2006) Desain Model Komponen Pneumatik untuk Media Pembelajaran Mekanisme Komponen Pneumatik. INVOTEC. III, (9), hlm. 116-124.

Rusman, dkk. (2012). Pembelajaran Berbasis Teknologi Informasi dan Komunikasi Mengembangkan Profesionalitas Guru. Jakarta: PT. Raja Grafindo Persada.

Sanjaya, W. (2010). Perencanaandan Desain Sistem Pembelajaran. Jakarta: Kencana Perdana Media Group.

Slameto. (2010). Belajar dan faktor-faktor yang mempengaruhinya, Jakarta: Rineka

Warsita, B. (2008). Teknologi Pembelajaran. Landasan \& Aplikasinya. Jakarta: RinekaCipta.

Wena, M. (2009). Strategi Pembelajaran Inovatif Kontemporer: Suatu Tinjauan Konseptual Operasional. Jakarta: Bumi Aksara. 